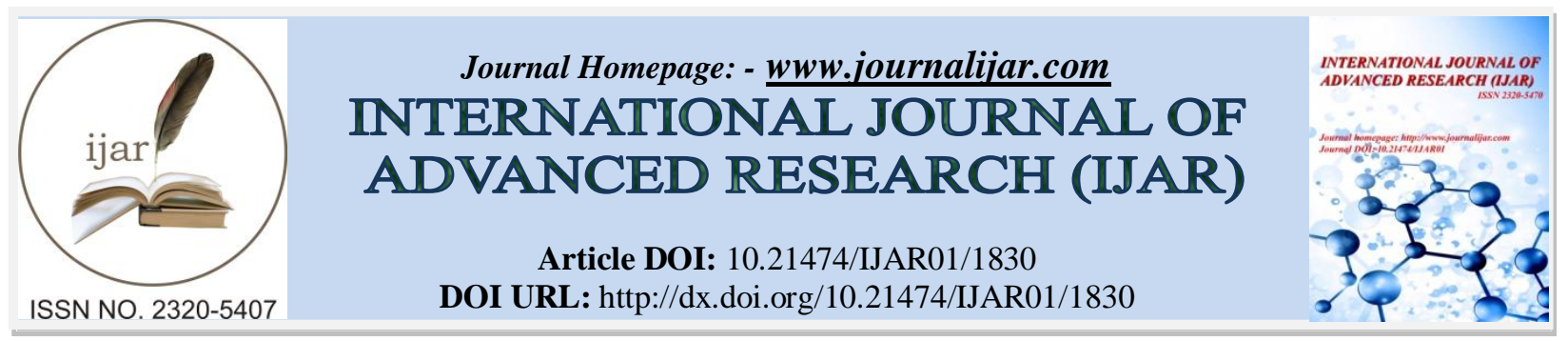

RESEARCH ARTICLE

\title{
CASE REPORT: CUMMIN SEEDS A CAUSE OF RECTAL IMPACTION.
}

Dr. Ramlal Prajapati ${ }^{1}$, Dr. Priyadarshini Manay ${ }^{2}$ and Dr. Anuj Sharma ${ }^{3}$.

1. Associate Professor, Department of General Surgery, Seth GS Medical College and KEM Hospital, Mumbai.

2. Assistant Professor, Department of General Surgery, Seth GS Medical College and KEM Hospital, Mumbai.

3. Registrar, Department of General Surgery, Seth GS Medical College and KEM Hospital, Mumbai.

\section{Manuscript Info}

Manuscript History

Received: 12 September 2016

Final Accepted: 22 October 2016

Published: November 2016

Key words:-

Home remedies, Cuminum cyminum.

\section{Abstract}

Cuminum cyminum or cummin seeds, a commonly known herb is used as a home remedy for treating minor ailments including indigestion, constipation and abdominal pains. Our case report is of a rare presentation in which this unsupervised and non regulated use of cummin seeds had led to rectal impaction of these seeds contrary to their role of providing relief. Hence, specifying the need for scientific evidence and rational use of these herbs for treating various ailments.

Copy Right, IJAR, 2016,. All rights reserved.

\section{Introduction:-}

Cuminum cyminum is a flowering plant that belongs to family Apiaceae. Known as KYMINON in Greek, JEERA in Hindi and KAMMUN in Arabic, it is extensively used in culinary practices of the Indian Subcontinent and some other Asian, African and Latin American countries ${ }^{1}$. It was known to Egyptian civilization five millennia ago and also has references in Bible. From local ailments like flatulence and indigestion to cancer and diabetes , the role of cumin seeds have been an area of interest both in the home remedies as well as in the medical research laboratories ${ }^{2}$. However, the lack of supervision by a trained medical personnel that comes with non regulated use of such herbs have brought forward few cases which led to complications of cumin seeds as impacted faeces, perianal pain and even impeding rectal perforation. Following are two rare case reports of unusual faecal impaction due to long term and excessive use of cumin seeds for indigestion.

\section{Case History 1:-}

$55 \mathrm{yr}$ old man, spice vendor presented with chronic constipation for 2-3 months with recent onset of perianal pain since 4 days. On taking further history he had complaints of vague abdominal discomfort since one year. Attributing it to dyspepsia or 'indigestion' he had turned to the traditional home remedies of consuming cumin seeds from time to time. However, he never took any medical practitioners' advice or any over the counter drugs for his complaints. He claimed the cumin seeds had relieved his symptoms temporarily. 
The per rectal examination revealed large quantity amount of undigested cumin seeds with minimal feces (Figure1).

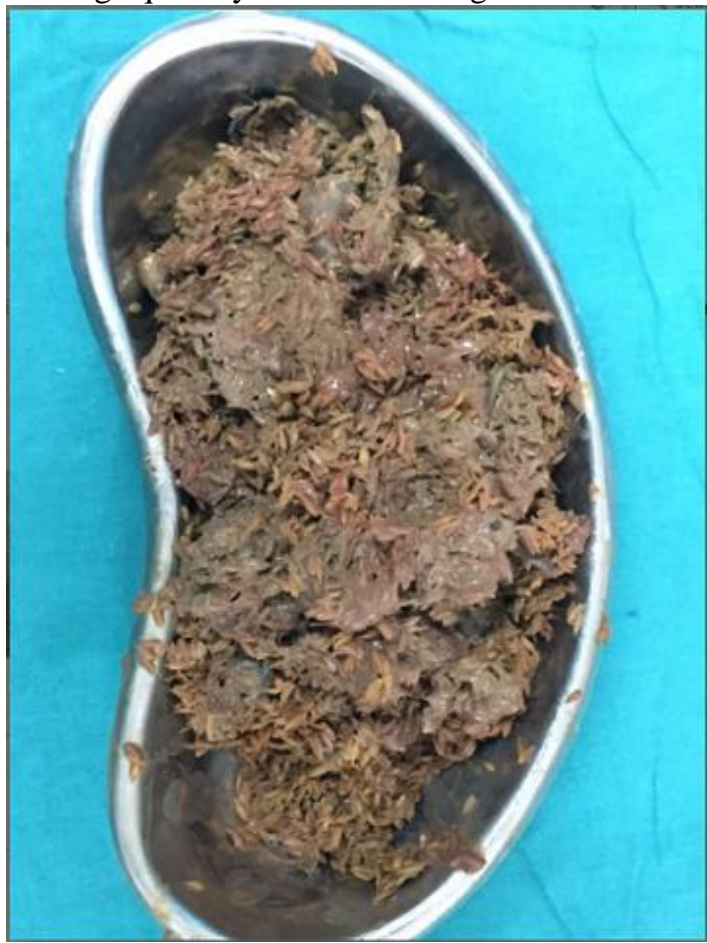

Figure 1:- Fecal matter mixed with Cummin seeds after manual removal of feces per rectally

\section{Case 2:-}

60 year old man was in the habit of consuming cumin seeds for chronic abdominal pain. He presented with abdominal distension and constipation since three months. Per rectal examination revealed gross quantity of cumin seeds and feces(Figure 2). The erect abdominal X-ray revealed air fluid levels.

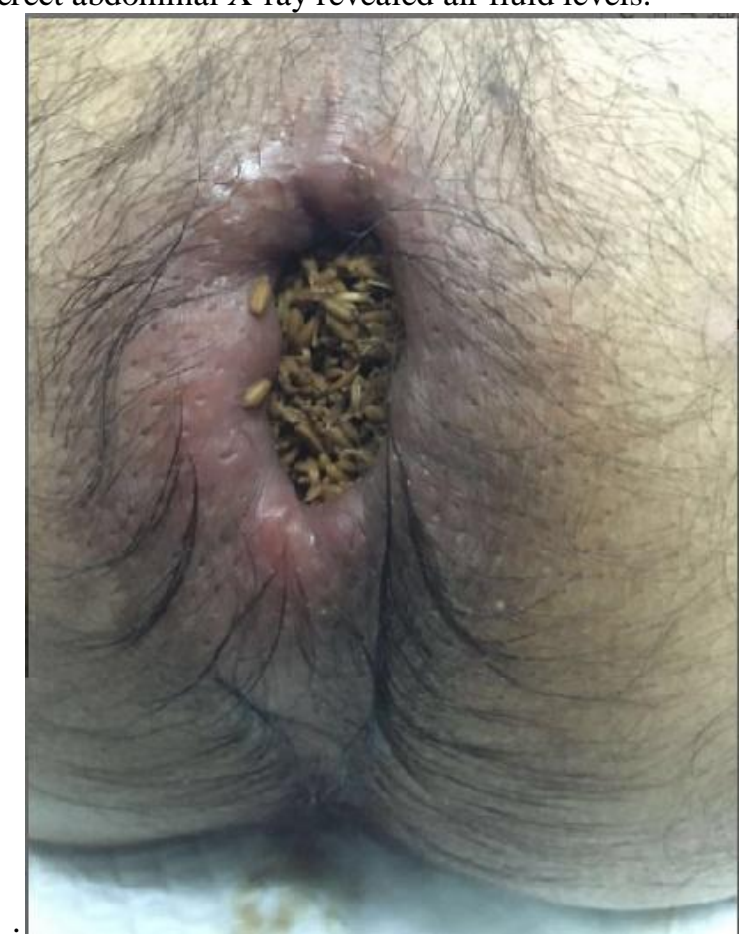

Figure 2:- Impacted feces with cummin seeds on visual per rectal examination of the patient. 
Both patients were managed conservatively with simple soap water enemas and laxatives per orally. When they did not respond they were taken up for manual removal of feces under anaesthesia. Figure 1 and 2 show the impacted cumin seeds present per rectally and the amount of cumin seeds removed manually.

Both the patients were relieved of the symptoms and were discharged with advise of stool softeners and high fibre diet. With dietary and lifestyle modifications they have been relieved of their dyspepsic and indigestion symptoms.

\section{Discussion:-}

'HOME REMEDIES' are simply prepared medications or tonic often of unproven effectiveness administered without prescription or professional supervision. Cummin seeds and its extracts are commonly used as home remedies for treating indigestion and altered bowel habits. Cumin contains volatile oil (3-4\%), cuminaldehyde, the major active principle, which is present to an extent of $45-50 \%{ }^{[3]}$ Alcohol and water extracts of cumin in literature have been reported to possess many nutraceutical properties like anti-diabetic ${ }^{[4]}$ antioxidant, ${ }^{[5]}$ anti-bacterial, ${ }^{[6]}$ antifungal, ${ }^{[7]}$ bronchodilatory, ${ }^{[8]}$ hepatoprotective and renoprotective, ${ }^{[9]}$ chemopreventive, ${ }^{[10]}$ anti-epileptic, ${ }^{[11]}$ Hypolipidemic, ${ }^{[12]}$ male anti-fertility ${ }^{[13]}$ memory-enhancing and anti-stress ${ }^{[14]}$ effect .Deoiled cumin, which generates from essential oil and oleoresin extraction Consists of 12.26\% SDF(Soluble Dietary Fiber) and 71.92\% IDF(insoluble dietary fiber). ${ }^{[15]}$ SDF appears to be more bioactive than IDF due to its fermentability and viscosity and has shown to increase bowel motility and decrease gut transit time. Approximately 30\% SDF should be consumed on a daily basis . ${ }^{[16]}$ The relatively low content of SDF in cumin seeds can explain its role contrary to its use for relieving constipation and improving altered bowel habits as traditional home remedy. Further in an experimental study conducted on albino mice by sahoo et al, ${ }^{[1]}$ aqueous extracts of cumin seeds have been shown to possess anti diarrhoeagenic properties with decrease in stool frequency and modest reduction in intestinal transit. The cause has been attributed to decreased prostaglandin synthesis(PGE1), reduced intestinal muscle contraction and decreased intestinal motility. Prolonged intake of cummin seeds causing rectal impaction leading to acute obstruction in our case may be explained by these very properties All these studies in literature and our case report throw light on the serious consequences which can happen by unsupervised and unregulated use of spices and herbs as home remedies.

\section{Conclusion:-}

Though prevalent in various cultures and ethinicity, home remedies need to be monitored and supervised by skill medical personnel having a sound knowledge of the literature, side effects or even hazards associated with them. By knowing the mechanism that might explain the indigestion and anti diarrhoeagenic properties of cumin extracts, there also arises a need to study evidence and scientific basis of the various other home remedies that are used routinely to treat minor ailments.

\section{References:-}

1. Thippeswamy, N. B., \& Naidu, K. A. (2005). Antioxidant potency of cumin varieties - Cumin, black cumin and bitter cumin - On antioxidant systems.European Food Research and Technology, 220 (5-6), 472-476.

2. Galisteo,Duarte,\&Zarzuelo,2012;Sowbhagya,Suma,Mahadevamma,\&Tharanathan,2007

3. Hafedh Hajlaoui, Hedi Mighri, et al Food and Chemical Toxicology, Volume 48, Issues 8-9, AugustSeptember 2010, Pages 2186-2192

4. Dhandapani S, Subramanian VR, Rajagopal S, Namasivayam N. Hypolipidemic effect of Cuminum cyminum L. on alloxane induced diabetic rats. Pharmacol Res.2002;46:251-5. [PubMed: 12220968]

5. Jagtap AG, Patil PB. Antihyperglycemic activity and inhibition of advanced glycation end product formation by Cuminum cyminum in streptozotocin induced diabetic rats. Food Chem Toxicol. 2010;48:2030-6. [PubMed: 20451573]

6. Iacobellis NS, Cantore PL, Capasso F, Senatore F. Antibacterial activity of Cuminum cyminum L. and Carum carvi L. essential oils. J Agric Food Chem. 2005;53:57-61. [PubMed: 15631509]

7. Romagnoli C, Andreotti E, Maietti S, Mahendra R, Mares D. Antifungal activity of essential oil from fruits of Indian Cuminum cyminum. Pharm Biol. 2010;48:834-8.[PubMed: 20645785]

8. Boskabady M, Kiani S, Azizi H. Relaxant effect of Cuminum cyminum on guinea pig tracheal chains and its possible mechanism (s) Indian J Pharmacol. 2005;37:111-5.

9. Aruna K, Rukkumani R, Varma PS, Menon VP. Therapeutic role of Cuminum cyminum on ethanol and thermally oxidized sunflower oil induced toxicity. Phytother Res. 2005;19:416-21. [PubMed: 16106395] 
10. Gagandeep DS, Mendiz E, Rao AR, Kale RK. Chemopreventive effects of Cuminum cyminum in chemically induced forestomach and uterine cervix tumors in murine model systems. Nutr Cancer. 2003;47:17180. [PubMed: 15087270]

11. Janahmadi M, Niazi F, Danyali S, Kamalinejad M. Effects of the fruit essential oil of Cuminum cyminum Linn. (Apiaceae) on pentylenetetrazol-induced epileptiform activity in F1 neurones of Helix aspersa. J Ethnopharmacol. 2006;104:278-82. [PubMed: 16226415]

12. Dhandapani S, Subramanian VR, Rajagopal S, Namasivayam N. Hypolipidemic effect of Cuminum cyminum L. On alloxan-induced diabetic rats. Pharmacol Res.2002;46:251-5. [PubMed: 12220968]

13. Gupta RS, Saxena P, Gupta R, Kachhawa JB. Evaluation of reversible contraceptive activities of Cuminum cyminum in male albino rats. Contraception. 2011;84:98-107. [PubMed: 21664518]

14. Koppula S, Choi DK. Cuminum cyminum extract attenuates scopolamine induced memory loss and stressinduced urinary biochemical changes in rats: A noninvasive biochemical approach. Pharm Biol. 2011;49:7028. [PubMed: 21639683]

15. Sowbhagya, H. B., Suma,P. F.,Mahadevamma, S., \&Tharanathan,R N. (2007). Spent residue fromcumin -A potential source of dietary fiber. Food Chemistry, 104 (3), 1220-1225

16. Galisteo, M., Duarte, J., \& Zarzuelo, A.(2012). Effects of dietary fibers on disturbances clustered in the metabolic syndrome. The Journal of Nutritional Biochemistry ,19 (2), 71-84

17. Sahoo HB, Sahoo SK, Sarangi SP, Sagar R, Kori ML. Anti-diarrhoeal investigation from aqueous extract of Cuminum cyminum Linn. Seed in Albino rats. Pharmacognosy Research. 2014;6(3):204-209. doi:10.4103/0974-8490.132596. 